\title{
The Reflection on Western Evolution of the Right of Personality
}

\author{
Miao Chungang ${ }^{1}$ \\ ${ }^{1}$ Department of Political and Law, North China Electric Power University, Baoding, Hebei, China \\ Correspondence: Miao Chungang. Tel: 86-139-3023-9061. E-mail: sdulmiao0753@sina.com
}

Received: June 22, 2017

Accepted: July 3, $2017 \quad$ Online Published: July 25, 2017

doi:10.5539/ass.v13n8p183

URL: https://doi.org/10.5539/ass.v13n8p183

\begin{abstract}
In the period of ancient Greece and the ancient Rome the sprout of the right of personality appeared. The modern renaissance, enlightenment, religious reform contributed to the formation of the modern civil law, and the rational personality can be established. On the basis of above, modern western legislation of rights of personality has different paradigms, such as France, Germany and Switzerland. Although the protection modes of all countries are very different, the idea of equal protection of personality are the same.
\end{abstract}

Keywords: personality, the right of personality, the law of France, the law of Germany

\section{The sprout of the personality right in the period of ancient Greece and the ancient Rome}

Similar to the evolution of human civilization, the law in early stage of human society started from the clan or tribe. People are the member of the community, whose personality is a collective personality of groups. Ancient Greece Solon had promoted the development of commodity economy, and provided material support for the aristocratic clan struggle of civilians. In the struggle, nobles competed with civilians and won in Cristini civilian revolution over the nobles. The clan eventually disintegrated, and individuals were gradually liberated from the group. In the early stage of Rome, there are struggles between commoners and nobles, but in the end, the two countries could not avoid the destiny of escaping from the stage of history. In Rome society, the aristocratic clan forces disappeared, and made the individual return to the family in the organization. Individuals only can get the personal right under the rule of parents, and are subject to parental authority.

"The concept of Rome personality was originally from Greece. In Greek philosophy, there was only the individual, not the overall concept, but the concept of individual is the only ethical concept in Greek, and the Romans took it over and used it as in legal system." (Wang, 2005) Generally, the use of the concept of personality was founded in Rome law. The right of personality is not equal in early Rome law, "at that time, the ethical factors, such as intrinsic value, human dignity and so on, are also excluded from the identification of personality, all the people can obtain the personality which completely depended on their social status and class membership" (Ma, 2008) In the right of parents, adult male parents was respected in families, and there was patriarchal supremacy, so later, there was the "good father" duty in civil law. In the family, parents have dominated family property right, the right of children and right of discipline. The relationship between husband and wife was serious inequality.

In the late of Rome, with the expansion of the Rome Imperial military and business, property transfer transaction is more and more frequent, which required individual personality gradually being separated from parents right. At the same time, with the spread of natural law thought, the idea of legal value of Rome had changed into the concept of equality in the latter half of Rome. During this period, the Rome Legalist standards gradually declined, and the right of parents has been challenged. The status of women in family relations has been greatly improved and the patriarchal relations of personal dependence has been reduced and gained more freedom of property. In the relationship between parents and children, the status of children has been improved in family, parents were not allowed to infringe the rights and interests so that the individual consciousness was awaked and became the first bud of modern individualism. Strengthening the individual consciousness improved the understanding of personality in the Rome law and produced more rights connotation.

In Rome law, there were the first relief provisions of the personality rights violations. Institutions provided provisions for unlawful infringement of personality rights: "the implementation of the illegal infringement has been done to someone under the condition of not only in the sticks beaten but also being scolded. Or if someone in order to destroy the reputation of others, write, edit, publish the satire or poetry, or claim infringement of 
chastity, unlawful infringement has also been implemented" (Zhou, 1994). Obviously, the personality right of Rome law has been damaged, and there has been other personality interest protection, but the study on Rome law personality system as a whole, will have the following characteristics: First, the scope of subject personality is very narrow, the main subject of the personality is limited to free people from the aspect of the whole society, and adult father from aspect of the family; Second, the scope of personality rights protection is relatively narrow, being confined to the life, health, reputation and chastity and other personal interests; third, in order of legal protection, the application of criminal law is prior to the civil law in Rome law.

\section{The formation of personality concept in modern civil law}

"The lex duodecim tabularum in Ancient Rome was home-based, and until the mid of Republic, Rome had been a home standard law. By the late Republic, with the development of economic and military expansion, home standard gradually collapsed and, legal concept of individual standard and legal system developed based on the home standard which had been denied." (Zhang, 2005) But in the long Middle Ages, legal concept individual standard had been strictly suppressed. In the middle ages, the power of religion permeated the whole of Europe. The right of personality had been out of the power of parent and gradually gone toward independence in the late of Rome law. So it became God's vassal again, to a certain extent was expansion of God standard. In the world, secular regime relied on powerful forces to maintain a level difference of reality. "The state rule and social control of the manor standard, the power of the church deeply affected the implementation of the law, and people's legal consciousness." (Zhu, 2005) Dual control of religious and secular kingship made it difficult to make individual personality to independent direction.

After the long and dark Middle Ages, by the end of the fourteenth Century European continent ushered the Renaissance originated from southern Italy. "The root cause of the rise of the Renaissance is that economic development of industry and commerce brought the prosperity of secular life in the city, but contrary to this, there were the dark shadows and the plague ridden in the middle ages." (Yu, 2006) In the Renaissance, humanism thought was put forward and gradually formed. The spirit of humanism requires respecting for people, caring for people, paying attention to one's own dignity and value, rather than belief in God, and then laid the initial foundation for concept of "personality equality" in the modern civil law; Secondly, the humanist pursuits rational dignity and the value of thinking, paying attention to earthly enjoyments. Renaissance inspired the spirit of humanism, provided a powerful ideological weapon to pursue happiness in reality, getting rid of the church rule, the realization of personal liberation for the emerging bourgeoisie.

The religious reformation after the Renaissance and, "established the Christian thought of human dignity through preaching the publicity was created by God, salvated by Christ and everyone is equal in the presence of God, which was the contribution to Western Europe and the wider world from Christian. It constituted the basic philosophy of the descendants in the Middle Ages" (Liang, 1997). From the perspective of legal concept, the religious reformation made human nature equal and human beings have dignity, both of which played an important role in the personality consciousness.

As the enlightenment the foundation of the French Revolution Thought, it further enhanced the liberation of ideological space and made the individual liberation from the group and the transition from group personality to independent personality. "The natural law of the enlightenment pushed the value of the individual to the legal front, while the previous single person just as members of the group concealed in the law. Based on the concept of natural rights, natural law school held the body, life, freedom and other interests in the country had been in existence before the formation of human, which was a kind of natural right, therefore, life, freedom and other personal interests should not only be protected in criminal law, but also the need to the protection in the civil law." (Wang, 2006) The enlightenment emphasized the liberation of personality, and advocated to carry out a comprehensive reform of the interests of the bourgeoisie in economic, political, social and other fields and to remove the obstacles for the development of capitalism. The French Revolution broke out in 1789, the declaration of human rights in the constitution of the programmatic document had greatly liberated the human nature, and made the protection of equality of personality, dignity, the personal interests as the national obligation, which should be the criteria followed by legislation and judgment.

From 14th to 17th century in Roman continent, the revival of Rome law, the rise of the Renaissance, the religious reformation produced its concept of modern civil law and developed the rational personality of the modern civil law. The spirit of humanism Contained in modern civil law began to sprout from Rome, and became eventually mature after repeated ideological liberation movement in modern times. Different from the early civil law, "the first modern civil law put forward the people's subjectivity. For the first time in human history, all life and equal rights were explicitly written into the code recognizing the independence and equality 
of people, making people free from the oppression of identity system, showing respect for people, confessing the spirit of humanism in people's Liberation." (Yu, 2006)

\section{The legislation of modern western personality right}

The right of personality, as the very important individual rights, had already existed in the ancient law, and the concept had ancient origins in Europe. Generally, the recognition of the right of personality rights as early modern humanism jurist was the achievements of Donellus. From now on, the concept of personality right has been endowed the spiritual pillar through the modern natural law and gradually formed." (Yu, 2006) To observe from the aspect of historical perspective, the concept of personality right was not very complete from the very beginning, rather as comprehensive appellation of a personality right to life, health, reputation and other of specific rights protected. (Chen, 2013)

Modern personality right as a new right generally following the value of respect developed in European countries. Modern personality right in European countries adapt to new changes in politics and economy, at the same time, being affected by the law in the nineteenth Century, so there was a significant change in the concept of personality protection. "At the beginning of nineteenth Century, the school of natural law was established based on the human rights and rational life, taking freedom, human rights born with talent as the basic human rights or human rights, so the concept of right of personality was gradually sprouted. Thereafter the interests of law school could claim this rejection to any right out of the law, but from the aspect of object of legal protection, it explored the nature of personality right, but the object of private law protection could not be limited to the physical property of the goods, although the spirit of intangible goods, also should be included in the declaration." (Zeng, 1931) The change of the concept of personality protection brought the differences of legislative models in the codification of modern civil law. In brief, to cater for the natural law trend of thought in the early nineteenth Century, there is no specific provision for the right of personality in Civil Code. It developed the right of personality through the interpretation of the 1382 clauses in the civil law; with the rise of the law of interests, the specific civil rights were clearly defined in the German Civil code; The Swiss rule became the model of modern personality right legislation protection. Different from the codification of the civil law system, the Anglo American Law in this period carried out the protection of personal rights in the form of case law.

\subsection{French Law}

Originated in England in seventeenth Century and developed in eighteenth Century, the enlightenment movement in France provided the ideological basis for the French Revolution. The French Revolution of 1789 overthrew feudal autocracy which had been in existence for a long time, which promoted the unification of French law. With the promulgation of the Declaration on citizens and human rights, the concept of freedom, equality and democracy had become increasingly popular, and has been gradually implemented in the follow-up legal implementation. Contained in Declaration of Human Rights as a constitutional program, the idea of equal protection of civil rights had been put into effect in Napoleon code.

In accordance with the requirements of the Declaration of Human Rights, the French Civil Code, which was the result of the French Revolution, for the first time regarded the equality of personality as the basic principle of civil law. The personality equality in this period was the personality equality in the abstract sense. It abandoned the identity under the feudal law and the restriction of rank to man. It emphasized that each civil subject had his own independent will, and he could participate in the market competition equally. But in 1804, when the French Civil Code was set, the theory of civil law had no territory of personality right, and lawmakers at the time could not imagine the existence of the right of personality, so in legislation it didn't make provisions for the right of personality, but this one had a profound social reason: First, from the social needs of the law, the French economy, science and technology in the early nineteenth Century was not yet developed, so as to there were no modern technology which brought the threat to psychology or emotion; Second, academic preparation is not adequate to get the right of personality included in the vision of the legislators. The academic field thought that natural person only enjoyed the right to dispose of objects and their own interests of creditor's rights and did not enjoy the right of personality.

Although there was no explicit title of personal right in the French civil code, but it did not lack the protection of personal interests. In the code arrangement style, it reserved the bigger development space for the personality rights and interests in the human law; in terms of tort, the provisions of the general provisions of the civil law was missed in the case of 1382, but its "there were on provisions only on the static damage of tort consequences but not on objects, and thus became a high level of abstraction in terms of capacity greatly and elastically" (Cao, 2009). This model of legislative formulation was inherited by civil law draft of Qing Dynasty then, and still exist in civil law of Taiwan area. By the opening legislation in the French civil law, through specific cases the natural 
person was determined to enjoy the interests of personality, not only in life, the body of personality interests, but also the spirit of personality interests reputation advocated in modern credit law, such as chastity, portrait, name, also got better protection in judicial practice in France.

Investigating social trends of the French Civil Code and examining the civil code after the practice of protecting the right of personality, we would have a comprehensive understanding of the protection of personality right in Civil Code. From the aspect of the code formulation, the natural law thought occupied the mainstream of society at that time, and the basic human rights existed before the national laws. The French believed that human rights were natural and human rights were not stipulated by the real law, which is higher than the protection of the real law. The right of personality should exist as a kind of natural right first, so it was not necessary to be protected. Therefore, there was no specific regulation of personal right in the code. However, the 1382nd article of the civil code, as the general clause of tort, has opened up a new pattern of protection of civil rights. The tort of fault emphasized the occurrence of damage, the subjective psychological state of intention or negligence, and then the establishment of tort liability can be confirmed by the causation of damage and fault, so as to construct a comprehensive protection system of civil rights. For the scope of damage, the civil code has achieved a high degree of flexibility, including both rights and interests. "The French civil law was not to look at the concept of personality right, but look at the personality from the higher and natural position. Though it didn't provide provisions of the right of personality in the sense of legal rights, but had higher protection of the personality than the protection of legal rights." (Long, 2002)

Although the French civil code has established the principle of equal personality, the equality of personality is more of a kind of personality equality in form, and still difficult to implement in the field of traditional family law. Family law has a strong ethical foundation and a natural rejection of social change. The residual paternalism in the French law showed that equality of personality was still a large resistance in the traditional family organization, and it was not hard to explain the profound influence of modern Chinese in patriarchy. So the implementation of equality of personality in the traditional family may not go smoothly. "The French Civil Code established that the equality of personality was one of the basic principles of civil law, and the equality of men and women should be the proper meaning of equal personality, but the provisions of article 213rd "the husband should protect his wife, and the wife should obey their husbands" (Li, 1979) showed personality inequality between husband and wife.

\subsection{German Law}

The German civil code, which came into force in 1900, was deeply influenced by German Kantian philosophy in the legislation of personality rights. Kant's philosophical ideas did not provide the philosophical basis for the objectification of human body, which advocated that personality meant human dignity, and interest could not be used as the object of civil legal relations. Savigny, who was deeply influenced by Kant's philosophy, denied that the subject of right had the right to himself, and even if he had it, he could not make the provisions of the substantive law. Savigny's elaboration of personality right and legislative mode profoundly influenced the legislation of personality right in Germany.

The codification of the German civil code had benefited from the overall acceptance of the Rome law as a whole, but it had not paid enough attention to the personality rights deduced from the Rome law on the issue of personality rights. Winter Zayed, a jurist who presided over the codification of the German civil code, was greatly influenced by Savigny. In its value logic, "he gave up the legal benefit of the personality itself as a protection of tort law" (Maxi, 2006). But in the form of legislation, the German civil code could not ignore the protection of life, body, health and freedom. The contradiction between the supply and need of the personality theory on the protection of the rights of social reality made that the German civil code to protect personal rights was embodied in the 823rd article. From the scope of the rights and interests protected by the law of tort liability, there was no general provision for the right of personality, nor had the right of personality in coordination with the real right. In the specific type of personality rights protection, only when the body, health or freedom is infringed, the victim enjoyed pecuniary compensation for non pecuniary damage.

For the protection of reputation related to moral evaluation, the German civil law did not explicitly stipulate, but indirectly protected by the second civil code of 1896. This provision of the civil code was in line with the provisions of the German criminal code in 185th article (crimes against reputation). It stated that any act of libel or insult committed by the perpetrator would constitute a criminal act of defamation if they committed defamation or insult. The protection of specific personality rights in German law was changing with the improvement of social public rights consciousness. First of all, in the twelfth article of German Civil Code, the right of name is stipulated separately, which specified the right of the owner to exclude the infringement when he 
was infringed. Secondly, in the copyright law of art and photography (1907), portrait rights and copyright personality rights were expanded, and the types of personality rights protection were expanded.

German civil law was formed in the late twentieth Century and early nineteenth Century. In the monopoly capitalist period of development, then the civil law socialization trend of thought had already come into being. For the German civil law, the German scholar Radbruch thought the legislative trend of the German civil code still insisted on individualism in the overall value of the legislation, which was remarked as " it is the prelude of twentieth Century, it is the end of nineteenth Century. In German Law, the public interest pursuit still mainly stayed in the field of property law. Similar to the French Civil Code and German Civil Code, the principle of equality of personality implementation in German Civil Code was still not completely. It established the legal protection of the principle of personality equality in general, but in the field of family law still retained a large number of male and female personality inequality provisions.

\subsection{The Swiss Law}

The Swiss civil law completed the legislation in December 10, 1907, and it was formally implemented in January 1, 1912. It was a representative code in the early twentieth Century, and formed its own distinctive features at the same time as the German law. The Swiss civil law has created a new paradigm of personality protection, which specified the provisions of personality rights, and defined the general provisions of personality protection. The twenty-eighth article of Swiss civil law stipulated the right of action when the personality was infringed, so that the protection of personality could be declared; at the same time, the provisions of the infringement of personality interests was made as compensation consolation in Switzerland law of obligation, in order to build a more comprehensive system of protection of personality.

\section{Conclusion}

The humanistic spirit contained in western civil law began to sprout from the Rome law. After the revival of the Rome law, the Renaissance and the religious reform, it eventually developed into a rational personality in modern civil law. In ancient Greece and early Rome, man was also a member of the clan, and it was hard to have an independent personality under the restrictions of the clans and nobles. But along with the development of commodity economy and the struggle of civilians, clan society gradually disintegrated in social change, and personal personality consciousness awakened. In the Rome period, after the dissolution of the clan, the family took the place of the group, and the family members were subject to the right of the parents. But in the later period of the Republic of Rome, the patriarchal system gradually disintegrated, thus laying the foundation of modern individualism. In the middle ages, the individual became a subsidiary of religion and had no independent personality. With the change of modern society, the rational personality of individual independence was formed in the process of codification of civil law, and became the basis of modern personality system. Since the beginning of the French Civil Code, personal interests were protected in the continental legal countries gradually. Although, due to the different historical traditions and multi dimension, the legislative model of personality right varied in different countries, but the idea of personality right system was the same. Along with the development of modern capitalist commodity economy, the abolition of the status hierarchy system, European countries gradually established a system of personality based on individual personality equality and the establishment of personality equality principle in turn promoted the development of Western capitalist economy.

\section{Acknowledgments}

This research was supported by "the Fundamental Research Funds for the Central Universities (Grant \# 2016MS146)".

\section{References}

Cao, Xianfeng. (2009). Personality, personality right and Chinese civil code. Science Press. P. 87.

Code Nepoleon. (1979). Translated by Li Haopei, The Commercial Press.

Long, Weiqiu. (2002). On the natural right of all persons and its contemporary approach -- Also on constitutional order and civil law positivism. Tsinghua Law Journal, 2.

Ma, Junju. (2008). Lecture notes on personality and personality rights (p. 36). Law Press.

Maxi Milian Fawkes. (2006). Law of Torts, Translated by Qi Xiaokun, Law Press.

Ren, Danli, \& Chen, Daoying. (2013). Study on the communication mechanism between constitution and civil law -- from the perspective of legal protection of personality rights. Law Press. P.54.

Violation of protective laws: a person who violates the law that protects others has the same obligation. 
Wang, Boqi. (2005). Modern legal thoughts and Chinese inherent culture (p. 246). Tsinghua University Press.

Wang, Liming. (2006). On the new development of personality right. Studies in Law and Business.

Wushilanqing. (2009). Personality Right Law. Translated by Ling Muxian, Ge Min, Peking University Press. P. 2.

Xingyeyingyi. (1997). People in private law - centered on the property law of civil law,translated by Wang Chuangyi, published in Civil and Commercial Law Review, Liang Huixing, Law Press, P. 159.

Yu, Huiyang, \& Yu, Lin. (2006). The Renaissance and modern civil law idea. Journal of Central South University (Social Science Edition), 12(4).

Yu, Huiyang, \& Yulin. (2006). The Renaissance and modern civil law idea breeds. Journal of Central South University (Social Science Edition), 12.

Zen, zhishi. (1931). On the protection of personal right. Grand Quarterly, 1(3).

Zhang, Zhongqiu. (2005). On the change of western individual standard law. Journal of Jiangsu Police Officer College.

Zhou, Yue. (1994). Rome Law (the first volume, p. 298). The Commercial Press.

Zhu, Yong. (2005). The principle of private law and the modernization of Chinese civil law, jurisprudential study, the sixth.

\section{Copyrights}

Copyright for this article is retained by the author(s), with first publication rights granted to the journal.

This is an open-access article distributed under the terms and conditions of the Creative Commons Attribution license (http://creativecommons.org/licenses/by/4.0/). 